\begin{tabular}{|l|l|l||}
\hline \multicolumn{2}{|c|}{ PublisherInfo } \\
\hline \hline PublisherName & $:$ & BioMed Central \\
\hline \hline PublisherLocation & $:$ & London \\
\hline \hline PublisherImprintName & $:$ & BioMed Central \\
\hline \hline
\end{tabular}

\title{
PTEN profiling
}

\begin{tabular}{|l|l|l||}
\hline \multicolumn{2}{|c||}{ ArticleInfo } \\
\hline \hline ArticleID & $:$ & 4246 \\
\hline \hline ArticleDOI & $:$ & $10.1186 /$ gb-spotlight-20011107-01 \\
\hline \hline ArticleCitationID & $:$ & spotlight-20011107-01 \\
\hline \hline ArticleSequenceNumber & $:$ & 317 \\
\hline \hline ArticleCategory & $:$ & Research news \\
\hline ArticleFirstPage & $:$ & 1 \\
\hline \hline ArticleLastPage & $:$ & 2 \\
\hline \hline & $:$ & RegistrationDate : 2001-11-07 \\
ArticleHistory & $:$ & OnlineDate \\
\hline \hline ArticleCopyright & $:$ & BioMed Central Ltd2001-11-07 \\
\hline \hline ArticleGrants & $:$ & \\
\hline \hline ArticleContext & $:$ & 130592211 \\
\hline \hline
\end{tabular}




\section{Jonathan B Weitzman}

Email: jonathanweitzman@hotmail.com

PTEN is a tumour suppressor that may act by de-phosphorylating another signaling molecule, phosphatidyl inositol (PI) 3-kinase. In the November 6 Proceedings of the National Academy of Science, Javor Stolarov and colleagues from the Cold Spring Harbor Laboratory describe the generation of an inducible system to examine PTEN function (Proc Natl Acad Sci USA 2001, 98:13043-13048). They describe a retroviral-based experimental procedure to create regulated ecdysone-inducible expression of PTEN in a human glioblastoma cell line. They then examined the effects of PTEN induction on gene expression profiles using cDNA microarrays (containing 14,000 IMAGE Consortium clones) and compared the results with cells that were treated with the drug LY294002, an inhibitor of PI 3-kinase. Stolarov and colleagues identified both down-regulated and up-regulated genes, including those involved in growth control (such as transforming growth factor $\beta$, TGF- $\beta$ ) and cholesterol biosynthesis (for example, HMG-CoA synthase). These genes were also affected by LY294002 treatment, confirming that PTEN functions via the PI 3-kinase pathway.

\section{References}

1. PTEN, a putative protein tyrosine phosphatase gene mutated in human brain, breast, and prostate cancer.

2. Proceedings of the National Academy of Sciences, [http://www.pnas.org]

3. Cold Spring Harbor Laboratory, [http://www.cshl.org]

4. Inducible gene expression in mammalian cells and transgenic mice. 